\title{
Dari Kuning Langsat Menjadi Putih: Representasi Identitas Kulit Perempuan Ideal Indonesia dalam Iklan Citra
}

\author{
Okta Pratiwi (Penulis Korespondensi) \\ Program Studi Ilmu Komunikasi, Universitas Muhammadiyah Yogyakarta \\ oktapratiwi63@gmail.com \\ Luthfianiza \\ Program Studi Ilmu Komunikasi, Universitas Muhammadiyah Yogyakarta \\ luthfianiza04@gmail.com \\ Diserahkan: 27 April 2020; Direvisi: 13 Oktober 2020; Diterima: 13 Oktober 2020
}

\begin{abstract}
Every woman certainly hopes to have a beauty that is admired by everyone. It's just that at this time the meaning of natural beauty seems to have been erased by beauty industry. Some ads show the ideal beauty, which is white, slim, and tall This study uses a semiotic method to analyze the research object. The object of research in this study is the advertisement of the twin versions of Citra White Lotion Indonesia, Santi and Sinta in 1996. The object of this study was analyzed using the analysis of Roland Barthes's semiotics which developed the thoughts of Ferdinand De Saussure. The purpose of this study was to determine the representation of the ideal Indonesian women's skin identity in Citra advertisements that changed from yellow langsat in the 1980s to white after the 2000s. The analysis is done through the signs that appear from the footage of scenes taken in the Image Ad, starting from the expression, gestures, and color combinations used.
\end{abstract}

Keywords: Citra Ads, Beauty, Representation, Semiotics

\begin{abstract}
Abstrak
Setiap perempuan pastinya berharap memiliki kecantikan yang dikagumi oleh semua orang. Hanya saja saat ini makna kecantikan alami seolah terhapus oleh iklan-iklan industri kecantikan. Beberapa iklan menampilkan cantik ideal yaitu yang berkulit putih, langsing, dan tinggi. Penelitian ini menggunakan metode semiotika untuk menganalisis objek penelitian. Objek penelitian dalam penelitian ini adalah iklan Citra White Lotion Indonesia versi kembar Santi dan Sinta Tahun 1996. Objek penelitian ini dianalisis dengan menggunakan analisis semiotika Roland Barthes yang mengembangkan pemikiran dari Ferdinand De Saussure. Tujuan dari penelitian ini adalah untuk mengetahui representasi identitas kulit perempuan ideal Indonesia dalam iklan Citra yang berubah dari kuning langsat di tahun 1980-an menjadi putih pasca tahun 2000-an. Analisis yang dilakukan yaitu melalui tanda yang muncul dari cuplikan adegan-adegan yang diambil dalam iklan Citra mulai dari ekspresi gerak tubuh, dan kombinasi warna yang digunakan.

Kata Kunci: Iklan Citra, Kecantikan, Representasi, Semiotik
\end{abstract}

\section{PENDAHULUAN}

Iklan menurut Mahmud Machfoedz adalah segala bentuk penyajian informasi dan promosi secara tidak langsung yang dilakukan oleh sponsor untuk menawarkan ide, barang atau jasa (Machfoedz, 2010). Kecantikan merupakan benteng pertahanan perempuan yang sekarang diserang industri kecantikan. Dalam arus globalisasi sekarang ini, ukuran ideal menurut nilai-nilai lokal terpinggirkan oleh pencitraan yang dilakukan secara masif oleh iklan-iklan komersial. Salah satunya adalah iklan Citra. Pada dekade 1980-an, iklan Citra menampilkan perempuan cantik dengan identitas kulit berwarna kuning langsat. Saat ini iklan Citra tidak lagi menampilkan kuning langsat sebagai kulit ideal, justru iklan ini menampilkan kulit berwarna putih sebagai kulit ideal. 
Sebuah penelitian oleh mengenai iklan produk kecantikan oleh Rina Nurul Aisyiyah (2013) menemukan bahwa gambaran kecantikan pada produk sabun Dove tahun 2006 versi "Real Beauty Real Friends" di iklan audio-visual yang kecantikan dari luar (outer beauty) dapat dilihat enam bagian yaitu wajah, rambut, kulit, ukuran dan bentuk tubuh, pakaian, serta tata rias (make-up). Dove "Real Beauty Real Friends" menunjukkan gambaran outer beauty ditunjukkan dengan adanya karakter kecantikan di Indonesia yang dimiliki oleh semua golongan, baik itu generasi tua maupun kaum muda, jenis profesi, dan cara berpakaian (Aisyiah, 2013).

Penelitian lainnya oleh Wulan Purnama Sari (2016) menemukan bahwa iklan Pond's White Beauty dengan bintang Gita Gutawa yang bertema "Cantik Putih Merona seperti Korea" menciptakan konflik budaya dalam hal makna kecantikan bagi perempuan Indonesia. Hal ini dibuktikan dengan melakukan analisis semiotik pada iklan Pond's White Beauty dengan temuan di dalamnya yang mana stereotip perempuan cantik merupakan perempuan yang berkulit putih seperti perempuan Korea. Hal ini bertolak belakang dengan ras yang dimiliki orang Indonesia sendiri, artinya genetik menjadi tolak ukur yang tidak dapat disamakan dalam sebuah iklan (Sari, 2016).

Iklan Pond's ini menyajikan kesadaran palsu yang mana perempuan Indonesia dapat memiliki kulit putih seperti perempuan Korea hanya dengan menggunakan produk Pond's. Berdasarkan analisis Marxist dapat dilihat bahwa iklan Pond's ini dibuat untuk kepentingan kaum kapitalis yang dalam hal ini produsen produk yaitu Unilever. Unilever sebagai kapitalis melakukan hegomoni para perempuan Indonesia untuk membeli produk kecantikan Pond's dengan menggunakan media iklan untuk menciptakan kesadaran palsu dalam pikiran para perempuan Indonesia tentang gambaran kecantikan (Sari, 2016).

Sama halnya dengan penelitian Rina Nurul Aisyiyah dan Wulan Purnama Sari, penelitian ini juga menganalisis mengenai produk kecantikan dan representasi perempuan di dalam iklan tersebut. Hal yang membedakan adalah Rina Nurul Aisyiyah mengangkat iklan sabun Dove versi "Real Beauty Real Friends" dan Wulan Purnama Sari meneliti iklan Pond's, sementara artikel ini mengangkat iklan Citra versi tahun 1980-an dan 2000-an sebagai objek yang diteliti. Tujuan penelitian ini adalah untuk menganalisis dan mendeskripsikan representasi identitas kulit perempuan ideal Indonesia dalam iklan Citra yang berubah dari kuning langsat di tahun 1980-an menjadi putih pasca tahun 2000-an. Hal ini dikarenakan masyarakat khususnya kelas menengah ke atas berbondong-bondong mengikuti model iklan suatu produk kecantikan yang ditampilkan melalui tayangan iklan tersebut.

\section{KERANGKA TEORI}

\section{REPRESENTASI}

Christopher Prendergast menyebutkan terdapat beberapa definisi untuk istilah 'representa-tion' sebagai rasa yang hadir untuk mewakili dua cara yang saling terkait, spasial dan temporal (Prendergast, 2000). Gunther Kress dan Theo van Leeuwen (1996) mengangkat representasi sebagai proses di mana pembuat tanda, baik orang dewasa atau anak, berusaha untuk membuat representasi beberapa objek atau entitas (Kress \& Leeuwen, 1996). Di sisi lain, Kate Bowles berpendapat bahwa representasi sering dianggap hanya pertanyaan tentang bagaimana media menggambarkan peristiwa, orang, dan ide, dan bagaimana penggambaran itu kemudian memengaruhi dunia nyata dari peristiwa, orang, dan ide (Bowles, 2002).

Salah satu alasan mengapa kita membutuhkan representasi adalah bahwa hal itu memungkinkan kita untuk memperoleh dan untuk mengungkapkan wawasan tentang sifat sesuatu. Hal itu sebabnya adanya beberapa bentuk representasi yaitu, seni, historis dan politik. Representasi mendefinisikan realitas dan itulah sebabnya kami tidak mungkin melakukannya tanpanya (Ankersmit, 2003). Proses representasi tidak hanya membuat makna hadir, namun mereka membangun makna itu. Seperti yang 
ditulis Simon Critchley, ada yang hampir tak tertahankan keingingan untuk mengisi dunia yang penuh makna (Critchley, 2004).

Representasi media dapat membangun perspektif yang bisa mendukung kepentingan ideologis dominan. Menurut Hebdige, subkultur menolak pengawasan dan penggabungan dengan menciptakan logika identitas dan kohesi internal mereka sendiri. Representasi media dan budaya dari ras tidak selalu menghasilkan stereotip. Namun, mereka juga yang berasal dari kelompok etnis minoritas, menurut Paul Gilroy (1987;1993). Representasi media sebenarnya dapat menyebabkan kerusakan. Misalnya saja orang Belanda pembuat film Theo van Gogh yang sering berada di media karena banyak polemiknya dilihat, dibunuh pada tahun 2003 tampaknya sebagai reaksi terhadap pembuatan filmnya, kisah pernikahan yang diatur dalam komunitas muslim. Jelas pembunuhan bukan hanya efek dari representasi media, tetapi kehadiran medianya tentu saja membuat dan pandangannya diketahui. Terdapat juga masalah representasi yang menyebabkan kerusakan pada seluruh kelompok orang, sebagai contoh ketika perempuan biasanya diwakilkan oleh media bahwa hanya mampu merawat anak atau mempersiapkan makanan, kerusakan dilakukan untuk memperkuat status perempuan dalam masyarakat umum (Webb, 2009).

Semakin meluasnya konsumsi media dalam kehidupan sehari-hari yang muncul adalah masalah teoritis yang dieksplorasi. Media massa ini yang berkontribusi penting di dalamnya yaitu massa sendiri, yang secara kultural dirampas masyarakat tanpa memiliki rasa identitas dan kepemilikan yang benar (Hoggart, 2004). Daripada mempertimbangkan teknologi media sebagai ancaman terhadap nilai-nilai dan tradisi sosial, atau cara revolusioner untuk mengubah pengalaman sensorik, Thompson berpendapat mereka bisa membantu mempertahankan dan memperbarui rasa identitas serta tradisi (Thompson, 1996). Jauh dari mentransmisikan ideologi dominan dari kelompok yang berkuasa terhadap massa, ia menyarankan bahwa produk media yang telah terputus dari konteks produksinya ditanamkan kembali khususnya lokal dan disesuaikan dengan kondisi material dan budaya yang ada di Indonesia (Thompson, 1994). Oleh karena itu, interaksi audiens dengan media tidak pasif atau 'parasosial' tetapi lebih dipahami sebagai konstitutif fitur kehidupan sehari-hari yang membawa peluang dan ancaman baik bagi audiens maupun produsen. Interaksi dengan media juga harus dipahami dalam hubungan dengan jenis interaksi sosial lain seperti percakapan tatap muka karena orang melakukan interaksi yang dimediasi bersama sebagai bentuk interaksi sosial (Scollon, 1998).

Media selebriti memberikan teladan bagi penampilan fisik kita sendiri. Beberapa dari kita menginvestasikan sejumlah besar uang untuk produk kosmetik dan operasi untuk lebih mencintai diri kita sendiri, dan untuk dicintai oleh orang lain. Kita harus percaya dengan penampilan natural, namun media seperti majalah wanita dan program-program televisi menuntun kita pada keraguan dan kecemasan diri. Hal tersebut merupakan kepribadian narsis yang muncul dalam begitu banyak identitas diri setiap orang, kesaksian kekuatan bukan dari struktur atau agensi tetapi dari strukturasi, karena itu banyak orang terus-menerus menghasilkan peran individualistis kami dalam masyarakat daripada secara kolektif bekerja untuk nya teknologi cetak dan kapitalis 'menciptakan kemungkinan bentuk komunitas baru yang dibayangkan' di mana komunitas lokal menjadi bersatu melalui bahasa umum dan identitas nasional (Anderson, 1991).

\section{METODE PENELITIAN}

Penelitian ini menggunakan jenis penelitian deskriptif kualitatif dengan paradigma kritis. Secara lebih operasional, penelitian ini menggunakan metode semiotika dari Roland Barthes untuk menganalisis objek penelitian. Objek penelitian dalam penelitian ini adalah iklan Citra White Lotion Indonesia versi kembar Santi dan Sinta Tahun 1996. Semiotika sebagai ilmu yang mengkaji tentang tanda sebagai bagian dari kehidupan sosial (Piliang, 2003). Semiotika kemudian dielaborasi sebagai 
hubungan tripartit yakni tanda (sign) yang merupakan gabungan dari penanda (signifier) dan petanda (signified) (Fiske \& Hartley, 1996).

Roland Barthes melanjutkan gagasan Saussure dengan memberi telaah pada interaksi antara teks dengan pengalaman personal dan kultural penggunanya. Interaksi antara konvensi dalam teks dengan konvensi yang dialami dan diharapkan oleh penggunanya. Gagasan Barthes ini dikenal dengan tatanan penandaan (order of signification), yang mencakup primary signification atau denotasi (makna sebenarnya sesuai kamus) dan secondary signification atau konotasi (makna ganda yang lahir dari pengalaman kultural dan personal). Makna konotasi inilah yang kemudian berkembang menjadi mitos. Dalam penelitian ini, penulis berusaha melakukan analisis semiotika, mulai dari primary signification sampai secondary signification pada iklan Citra White Lotion Indonesia versi kembar Santi dan Sinta Tahun 1996.

\section{HASIL DAN PEMBAHASAN}

KONSTRUKSI KECANTIKAN DALAM MEDIA

Konstruksi yang dimaksud adalah opini yang sengaja dibentuk oleh media yang membuat masyarakat merasa yakin bahwa apa yang diberikan atau disuguhkan oleh media merupakan hal yang harus diteladani dan mutlak kebenarannya. Beberapa hal yang disampaikan oleh media menuntut kita harus meniru dan melakukan hal yang sama dan akan membuat masyarakat memandang bahwa itu sudah menjadi standar yang baik dan benar. Kecantikan yang dikonstruksikan media massa melalui iklan dijelaskan bahwa teks media merupakan konstruksi berdasarkan realitas sosial, sama halnya dengan kecantikan. Dalam masyarakat, kecantikan memiliki standar yang ditetapkan oleh masyarakat itu sendiri. "Beauty is pain" merupakan satu kalimat yang dipegang teguh sebagian besar perempuan. Untuk mencapai kecantikan, banyak usaha yang berat harus dilakukan. Penampilan fisik adalah syarat utama untuk menjadi cantik. Citra-citra ideal tentang gambaran perempuan yang cantik yang terusmenerus dikonstruksikan dan ditanamkan serta disosialisasikan melalui media secara perlahan tapi pasti telah berubah menjadi standar budaya mengenai kecantikan perempuan yang mengendap dalam kesadaran kita. Standar inilah yang kemudian menggiring perempuan ke perburuan kecantikan yang tanpa akhir dalam siklus pencarian kepuasan yang sebenarnya hanya menjerumuskan mereka ke dalam penjara baru kesepian dan alienasi yang dalam (Ibrahim, 2004).

Untuk menjadi cantik atau terlihat cantik, perempuan tidak selalu harus yang memiliki kulit wajah yang putih atau cerah dan awet muda seperti yang banyak dikonstruksi oleh media massa saat ini, terutama melalui iklan-iklan produk kecantikan. Mereka melihat bahwa nyatanya banyak perempuan yang sudah tua dan memiliki banyak kerutan ataupun memiliki kulit wajah coklat tetap dapat terlihat cantik ketika kulit wajah mereka tetap bersih dan terawat serta tidak kusam. Bentuk tubuh ideal yang diekspose oleh media massa memberikan ekspektasi tinggi pada perempuan terhadap tubuhnya sendiri. Pengulangan penyajian bentuk tubuh ideal tersebut mempengaruhi bagaimana perempuan membandingkan tubuhnya dengan tubuh ideal yang ditampilkan melalui media. Ketika perempuan mendapati kesenjangan antara citra tubuh ideal dengan citra tubuh yang nyata maka seringkali muncul ketidakpuasan akan tubuh dan keinginan untuk mencapai citra tubuh ideal. 


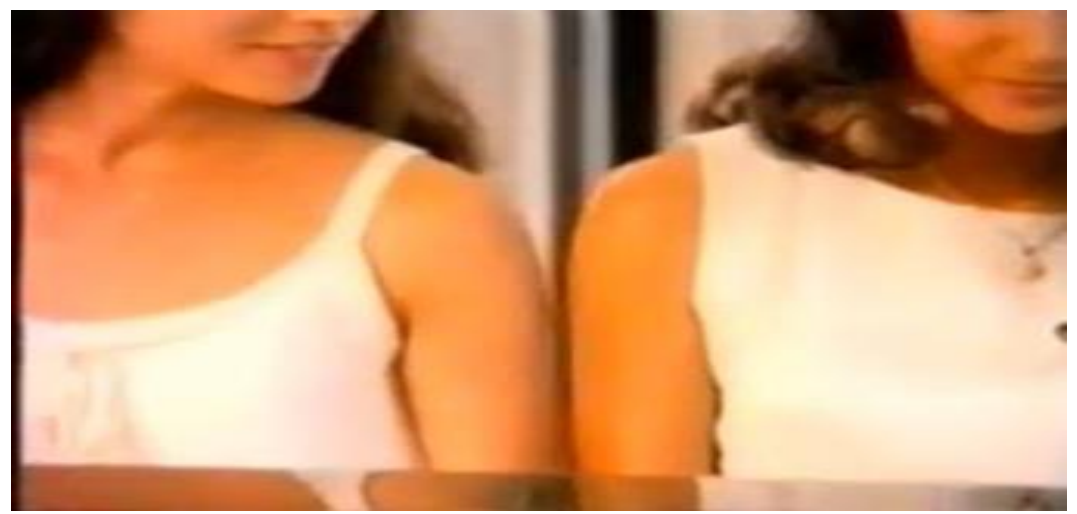

Gambar 1. Iklan citra white lotion Indonesia versi kembar Santi \& Sinta Tahun 1996 (Youtube, 2013)

Makna denotasi, petanda yang terdapat dalam potongan iklan Citra pada gambar di atas adalah dua orang wanita kembar yang berbeda warna kulit dan duduk berdampingan menggunakan baju putih berambut panjang dan digerai. Dalam adegan pada iklan ini juga didukung dengan audio yang berbunyi "Bagai pinang dibelah dua, kecuali warna kulit Santi tak seputih Sinta". Tanda yang muncul disini sangat jelas yaitu walaupun kembar namun kulit mereka berbeda, salah satu cenderung berkulit lebih putih.

Makna konotasi, kulit putih. Gambar potongan pada iklan Citra di atas adalah menampilkan makna dua perempuan kembar Sinta dan Santi yang saling berdampingan namun mereka mempunyai warna kulit yang berbeda, perempuan disebelah kiri (Sinta) cenderung memiliki warna kulit yang lebih putih dan perempuan disebelah kanan (Santi) memiliki kulit yang lebih gelap. Mereka menggunakan baju berwarna putih, namun Santi yang memiliki kulit lebih gelap cenderung bajunya lebih tertutup sedangkan Sinta bajunya lebih terbuka. Rambut mereka pun sama-sama digerai namun Santi lebih menyisihkan rambutnya kedepan seolah-olah ingin menutupi kulit gelapnya, beda dengan Sinta yang rambutnya digerai kebelakang semua sehingga terlihat putih dan bersih. Jika diperhatikan Sinta juga tampak lebih sumringah daripada Santi yang cenderung menunduk dan murung.

Layaknya makna tersirat yang terkandung dalam gambar pada Iklan Citra White Lotion Indonesia Versi Kembar Santi dan Sinta Tahun 1996 tersebut yang mengartikan bahwa mereka kembar namun kulit mereka tidak senada, kulit Sinta cenderung lebih putih dibandingkan kulit Santi sehingga membuat kembarannya Santi merasa iri dengan Sinta. Dilihat dari penggambarannya yang mana mereka duduk bersampingan dengan mengenakan baju putih namun tampak terlihat berbeda warna kulit mereka. Terlihat bahwa Santi yang memiliki kulit cenderung lebih gelap berpose menunduk dan murung. Seolah-olah Santi yang memiliki kulit lebih gelap merasa sedih dan tidak percaya diri dengan dirinya sendiri.

Saat ini tidak sedikit para perempuan yang mulai waspada terhadap diri mereka masing-masing yang merasa tidak percaya diri dengan apa yang mereka miliki. Bahkan mereka dapat melakukan hal-hal yang diluar dugaan atas tuntutan masyarakat dan media yang dapat menyebabkan gangguan internal. Namun, bila dipikirkan kembali tidak semua yang dikonstruksikan oleh media selalu yang dianggap benar atau selalu yang dianggap sempurna. Hal ini dikarenakan masih banyak perempuan yang memiliki kulit yang cenderung tidak putih namun bisa terlihat cantik bahkan lebih dari perempuan berkulit putih yang diidam-idamkan banyak orang.

Untuk saat ini sangat diperlukan sekali kesadaran masyarakat mengenai konstruksi kecantikan oleh media massa yang tidak selamanya harus menjadi cerminan diri yang ideal. Banyak sekali hal yang harus 
ditanamkan kepada diri perempuan bahwa "tubuhmu adalah bagian dari dirimu yang indah", harusnya layak dan patut untuk dicintai dan dirawat sebaik mungkin. Tidak melulu perihal putih, cantik, tinggi, dan rambut yang panjang berwarna hitam.

\section{PEMAKNAAN PUTIH SEBAGAI SIMBOL CANTIK}

Makna simbol pada konsep ini yaitu memperlihatkan tanda dan denotasi yang ditentukan suatu peraturan yang berlaku umum. Pada iklan yang diteliti memperlihatkan tanda tersebut menjadi umum untuk disebutkan dalam bermasyarakat yaitu bagaimana masyarakat melihat warna kulit yang putih sudah menjadi tanda umum seseorang disebut cantik di Indonesia. Simbol-simbol kecantikan yang berubah dari waktu ke waktu merupakan proses rekonstruksi yang dilakukan oleh sekelompok orang yang memiliki kepentingan di dalamnya.

Dalam konteks ini kelompok yang memiliki kepentingan adalah industri kecantikan. Simbol kecantikan bisa bermakna sesuatu yang diperlihatkan ataupun yang disembunyikan. Seperti yang dikatakan oleh Abdullah bahwa sebenarnya tubuh manusia awalnya adalah tubuh alami tetapi kemudian mulai bergeser menjadi tubuh sosial atau fakta sosial (Abdullah, 2006). Tubuh sosial atau fakta sosial bisa dipahami sebagai tubuh seorang individu adalah cerminan atau tuntutan dari tubuh yang diidam-idamkan masyarakat pada umumnya (Sari, 2019).

Mitos yang berkembang dalam masyarakat kita tentang warna kulit perempuan, bahwa warna kulit ini dijadikan sebagai pembeda tingkat sosial seseorang di masyarakat. Mitos yang berkembang dalam masyarakat kita tentang warna kulit perempuan, bahwa warna kulit ini dijadikan sebagai pembeda tingkat sosial seseorang di masyarakat. Artinya "cantik" sudah ditafsirkan menjadi hasrat baru. Hasrat tentang kesempurnaan tubuh yang direproduksi dan menjadi "kekuasaan” baru bagi perempuan. Mereka juga merasa tidak percaya diri dengan dirinya sendiri sehingga mereka melakukan cara apapun untuk menjadi cantik seperti tolak ukur atau patokan cantik ideal menurut mereka. Memiliki tujuan untuk menaikkan level kecantikan yang telah dimiliki mungkin sudah menjadi impian semua wanita.

Hingga saat ini, iklan kecantikan masih banyak menggunakan perempuan yang memiliki kulit putih. Hal ini berdampak pada cara pandang para perempuan bahwa memiliki jenis kulit putih, itulah cantik. Melalui kemajuan teknologi yang semakin modern, kecantikan secara fisik lebih mudah terwujud. Perempuan pemuja kecantikan secara fisik kemudian berbondong-bondong memoles bahkan mengubah diri menjadi lebih cantik. Banyak masyarakat sebagai konsumen semakin pintar dalam memilih sebuah produk kecantikan untuk di konsumsi dan lebih melihat kegunaan produk tersebut.

Wiasti memaparkan bahwa pada mulanya masyarakat Indonesia tidak memiliki orientasi makna kecantikan pada kulit putih tetapi lebih kepada kulit kuning langsat (Sari, 2019). Melalui produkproduk kecantikan yang populer pada zaman itu, berkulit kuning langsat adalah impian seluruh wanita Indonesia. Akan tetapi, pergeseran makna cantik adalah kuning langsat menjadi cantik itu putih dimulai pada era 1985-an. Produk-produk kecantikan yang awalnya berorientasi pada kulit kuning langsat sekarang mulai bergeser kepada kulit putih. 


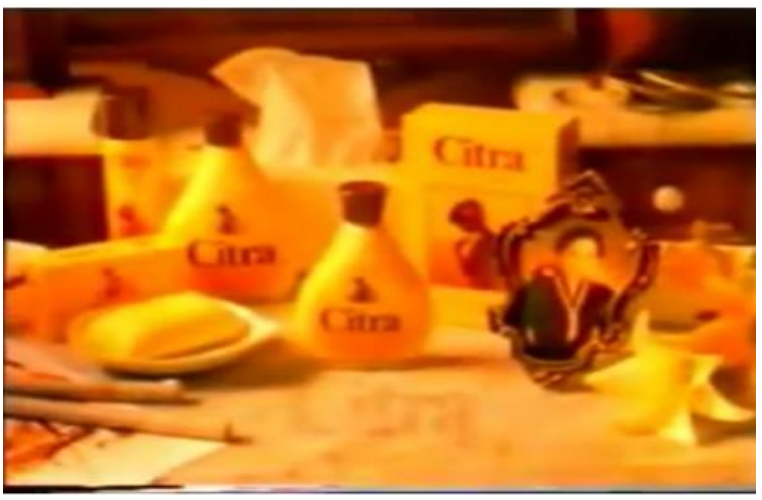

Gambar 2. Iklan citra tahun 1990 Putri Keraton (Youtube, 2018)

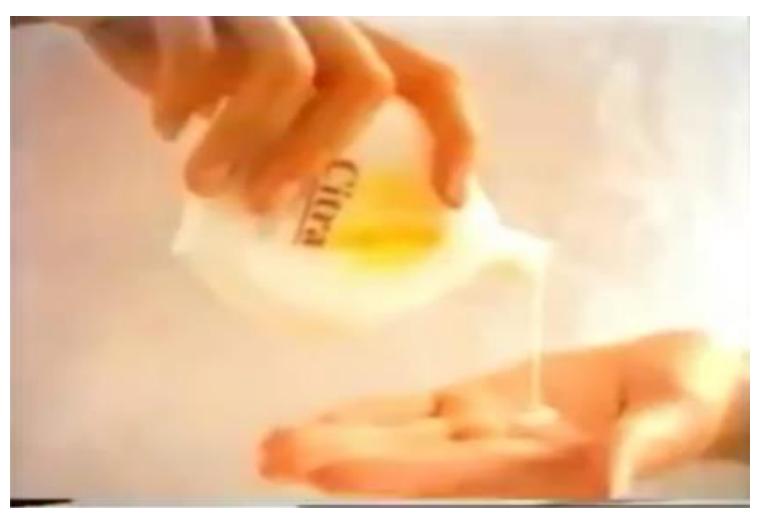

Gambar 3. Iklan citra tahun 1996 versi kembar Santi \& Sinta (Youtube, 2013)

Hal tersebut berdampak pada iklan produk Citra yang dipercaya sebagai produk warisan budaya Indonesia yang merepresentasikan kecantikan wanita. Pada awal kemunculannya, sebenarnya cantik yang ditawarkan oleh Citra adalah yang memiliki kulit kuning langsat. Hal ini dapat dilihat melalui iklan yang ditayangkan di televisi sejak kemunculannya pertama kali pada awal tahun 1990-an. Iklan Citra yang muncul di awal tahun 1990-an menampilkan sosok putri keraton yang merepresentasikan kecantikan. Konsep ini memproduksi isu lama yang mengatakan keanggunan dan kecantikan dari putri keraton. Kemasan dalam produk tersebut juga terus berubah mengikuti kontruksi yang ada, pada iklan Citra Putri Keraton warna kemasan cenderung kuning dengan tube botol berwarna coklat, sedangkan produk pada iklan Citra versi Kembar sudah menampilkan warna putih pada kemasannya. Warna putih di Indonesia diasosiasikan sebagai watak positif, merangsang, cerah, tegas mengalah. Selain itu juga melambangkan sebuah cahaya, kesucian, kemurnian, ketulusan, kejujuran, kelembutan, kewanitaan, kebersihaan, simpel (Rahardjo, Dektisa, \& Maer, 2016).

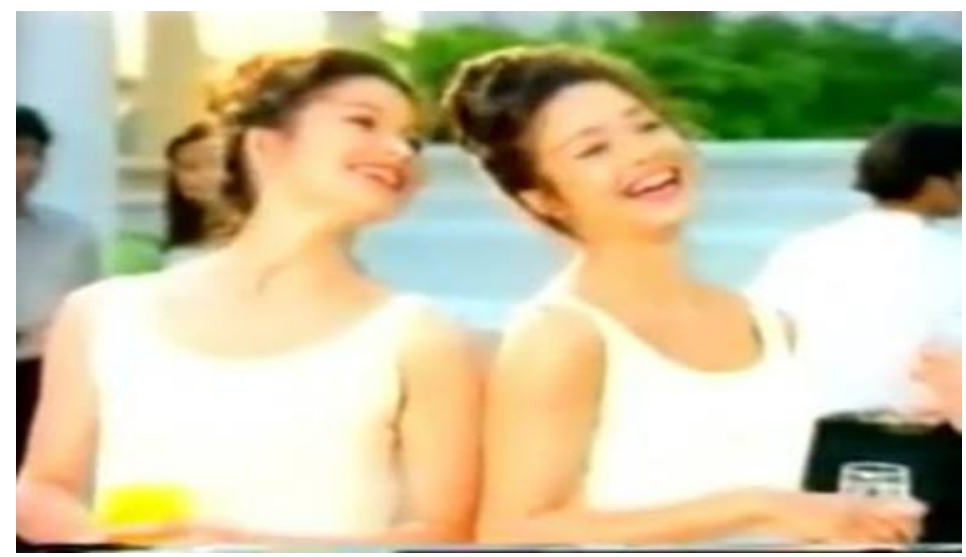

Gambar 4. Iklan Citra tahun 1996 versi kembar Santi \& Sinta (Youtube, 2013)

Makna denotasi, petanda yang muncul dalam potongan iklan di atas ialah Santi dan Sinta menggunakan baju berwarna putih dengan model yang sama. Selain itu gaya rambut keduanya juga sama yaitu dengan diikat ke atas. Santi dan Sinta berdampingan dengan raut muka ceria. Pada adegan tersebut juga didukung dengan audio yang berbunyi "Sekarang mereka sungguh bagai pinang tak terbelah", menjelaskan bahwa Santi dan Sinta sangat mirip. 
Makna konotasi, kulit putih membuat bahagia. Tampilan Santi dan Sinta pada potongan iklan tersebut sama dari segi baju dan rambut, keduanya menggunakan baju yang sedikit terbuka dan rambut yang diikat ke atas menandakan kepercayaan diri menampilkan warna kulit yang dimiliki. Mereka juga tampak ceria dan bahagia, terutama Santi yang semula memiliki kulit gelap, kini berubah menjadi putih. Potongan iklan tersebut menunjukkan bahwa tidak ada lagi perbedaan antara Santi dan Sinta, terlebih kulit mereka yang sama-sama berwarna putih setelah menggunakan Citra.

Pada akhir iklan Citra Versi Kembar \& Sinta digambarkan ekspresi Santi yang ceria, bahagia dan tampak lebih percaya diri setelah menggunakan produk Citra. Berbeda dengan scene awal iklan yang menampilkan ekspresi Santi yang digambarkan dengan gestur tubuh menunduk dan raut muka sedih tanda kurang percaya diri. Iklan tersebut memvisualisasikan bahwa seseorang akan terlihat bahagia jika memiliki kulit putih yang dianggap sebagai kulit ideal Indonesia.

Tabel 1. Oposisi Biner dalam Iklan Citra

\begin{tabular}{cc}
\hline \multicolumn{2}{c}{ Oposisi Biner dalam Iklan Citra } \\
\hline Cantik & Jelek \\
Putih & Hitam \\
Langsing & Gemuk \\
Tinggi & Pendek \\
\hline
\end{tabular}

Data diperoleh dari kategorisasi penulis (Penulis, 2020)

Dari oposisi biner tersebut dapat diketahui bahwa kulit putih kemudian menjadi ukuran cantik atau tidaknya seseorang, sehingga banyak wanita berbondong-bondong memutihkan kulitnya. Di setiap iklannya, Citra selalu menunjukkan bahwa kulit putih merupakan simbol kecantikan yang dikagumi oleh banyak orang, sehingga perempuan yang tidak berkulit putih dianggap tidak cantik. Ketika melihat iklan, masyarakat cenderung melihat apa yang divisualisasikan, iklan Citra selalu memvisualisasikan bahwa perempuan cantik yaitu perempuan yang berkulit putih, langsing, dan tinggi. Hal ini sebagai perwujudan dari kecantikan yang dihasilkan apabila menggunakan produk yang diiklankan tersebut.

Dalam iklan tersebut dapat diartikan bahwa dalam iklan berusaha menggambarkan konsep ideal wanita cantik di Indonesia pada masa tersebut adalah yang berkulit putih, dan konsep tersebut menganggap bahwa wanita berkulit kuning langsat atau sawo matang bukanlah warna kulit ideal. Fenomena yang terus berkembang bahwa cantik itu berkulit putih muncul karena derasnya arus informasi dari luar, karena perkembangan komunikasi yang begitu cepat. Citra kemudian hadir melalui produk kecantikan yang membuat kulit menjadi putih. Hal ini terlihat dari iklan yang ditampilkan sejak awal tahun 2000-an. Alhasil, iklan berhasil membuat realitas baru tentang kecantikan yang akhirnya menjadi wacana dan diikuti oleh kebanyakan perempuan di Indonesia.

\section{KESIMPULAN}

Berdasarkan hasil analisis tersebut representasi perempuan berkulit putih yang sengaja dibentuk oleh media masih sangat kuat. Hal ini dibuktikan melaui konstruksi kecantikan yang dibentuk oleh media saat ini yang membuat banyak para perempuan menganggap bahwa kecantikan itu yang ditampilkan di media massa, diluar itu dianggap buruk. Tuntutan yang dibuat oleh media yang mengharuskan perempuan untuk memiliki kulit putih itu sangatlah menjadi tekanan. Namun, pada dasarnya perihal sesuatu yang ditampilkan oleh media tidak serta merta bisa menjadi patokan. Dalam iklan kecantikan masih banyak menggunakan perempuan yang memiliki kulit putih, pun tidak banyak 
juga yang menampilkan perbedaan kulit didalamnya. Hal ini berdampak pada cara pandang para perempuan bahwa memiliki jenis kulit putih, itulah cantik.

Selanjutnya, dari analisis ditemukan bahwa media merepresentasikan perempuan dalam Iklan Citra White Lotion Indonesia Versi Kembar Santi \& Sinta Tahun 1996 ini dengan perbedaan warna kulit yang signifikan membuat salah satu dari mereka yang memiliki kulit cenderung lebih gelap merasa tidak percaya diri, seolah-olah kulit putihlah yang menjadi standar kecantikan perempuan. Dibandingkan dengan Iklan Citra Versi Putri Keraton Tahun 1990 menampilkan sosok putri keraton berkulit kuning langsat yang merepresentasikan kecantikan. Kemudian dapat disimpulkan bahwa dari adanya representasi iklan demi iklan yang ditampilkan oleh Citra, terdapat cara pandang yang berkembang dimulai dari cantik itu layaknya putri keraton yang dominan memiliki kulit kuning langsat. Hingga pada akhirnya media kembali membentuk representasi baru atas perempuan cantik yaitu perempuan yang memiliki kulit putih.

\section{PERSANTUNAN}

Terima kasih kepada Dr. Fajar Junaedi yang telah membimbing proses riset dalam mata kuliah Kajian Kritis Iklan di Program Studi Ilmu Komunikasi UMY, selama satu semester genap tahun akademik 2019/2020 yang menghasilkan luaran berupa artikel ini.

\section{REFERENSI}

Aisyiyah, R. N. (2013). Kecantikan dalam Iklan: Gambaran Kecantikan dalam Iklan Sabun Dove di Televisi. Journal Ilmu Komunikasi, 1(4), 63-80.

Laughey, D. (2007). Key Themes in Media Theory. New York: Open University Press.

M.Ds, F. (2018). Makna Cantik dalam Iklan Magnificent Meaning in Advertising. Jurnal Ilmiah LISKI (Lingkar Studi Komunikasi), 4(1), 1-12.

Machfoedz, M. (2010). Komunikasi Pemasaran Modern. Yogyakarta: Cakra Ilmu.

Rahardjo, S., Hagijanto, A. D., \& Maer, B. D. A. (2016). Mitos Kecantikan Wanita Indonesia Dalam Iklan Televisi Produk Citra Era Tahun 1980-an, 1990-an Dan 2010-an. Jurnal DKV Adiwarna, 1(8), 1-14.

Sandhy, A., \& Dwiningtyas, D. (2016). Pemaknaan Perempuan Terhadap Konstruksi Mitos Kecantikan dalam Media Online Femaledaily.com. Interaksi Online, 4(4), 1-11.

Sari, I. P. (2019). Rekonstruksi dan Manipulasi Simbol Kecantikan. Jurnal Hawa: Studi Pengarus Utamaan Gender dan Anak, 1(1), 1-18.

Sari, W. (2016). Konflik Budaya Dalam Konstruksi Kecantikan Wanita Indonesia (Analisis Semiotika Dan Marxist Iklan Pond's White Beauty Versi Gita Gutawa). Jurnal Komunikasi, 7(2), 198-206.

Webb, J. (2009). Understanding Representation. Los Angeles: Sage Publications Ltd.

Worotitjan, H. G. (2014). Konstruksi Kecantikan Dalam Iklan Kosmetik Wardah. Jurnal E-Komunikasi, 2(2), 1-10.

Youtube.com. (31 Januari 2013). Iklan Citra White Lotion - Kembar (Santi \& Sinta). Diakses dari https://www.youtube.com/watch?v=qsn-qZYDh2Y

Youtube.com. (15 Mei 2018). Iklan Citra Beauty Lotion - Perhiasan (1995-1996). Diakses dari https://www.youtube.com/watch?v=jqbC2njlwKk 